\title{
SEED GERMINATION AND MORPHO- PHYSIOLOGICAL CHARACTERIZATION OF THREE TOMATO (LYCOPERSICON ESCULENTUM) VARIETIES IRRIGATED WITH TREATED WASTEWATER
}

\author{
I. ZOUAGRI ${ }^{1}$, F. BEKHOUCHE ${ }^{1}$, A. KHELOUFI ${ }^{2 *}$, L. NOURI ${ }^{2}$ \\ *E-mail: abdenour.kheloufi@yahoo.fr
}

Received: Nov. 06, 2019. Revised: Jan. 16, 2020. Accepted: Jan. 23, 2020. Published online: Mar. 06, 2020

\begin{abstract}
The ability to reuse treated wastewater (TWW) would be of significant benefit to agriculture whilst at the same time providing a valuable water resource. This study concerned the effects of three various levels of treated wastewater $(0 \%, 50 \%$ and $100 \%$ TWW $)$ on seed germination and plant development of three different varieties of tomato (Lycopersicon esculentum) (viz. Toufan, Heinz and Bouzina). Irrigation with TWW persisted 15 days for the germination stage and 120 days for the growth and development stage. A control plot irrigated with a pure water (groundwater) was also set up in order to compare the seeds and the plants response to different concentrations of irrigation water. The final germination was expressed as a percentage of the total number of seeds in each treatment. This study has demonstrated that treated wastewater improves the germination in
\end{abstract}

Heinz variety and had no effect on both Toufan and Bouzina varieties whether it is pure or diluted by half. For the growth stage, the statistical analysis showed that the Toufan variety has tolerated successfully the TWW irrigation with its high and moderate concentrations, and this by analysing all the morphophysiological parameters studied in this work (leaves numbers, stem and root length and dry biomass, relative water content and rate water loss).

Keywords: wastewater reuse; water quality; experimental crops; plant growth; salinity; agriculture.

\section{INTRODUCTION}

Sustainable water management is one of the main focuses of sustainable development, as water must satisfy

\footnotetext{
${ }^{1}$ Faculty of Sciences, Department of Biology, Laboratory of Plant Biology and Environment, University of Badji Mokhtar, Annaba, Algeria

2 Department of Ecology and Environment, University of Batna 2, Batna, Algeria
} 
current and future generations (Loucks and van Beek, 2005). In addition, agriculture is the largest consumer of water resources. Given the scarcity of conventional water resources, we cannot neglect the idea of reusing the enormous quantities of wastewater discharged into the wild or into the sea (Jones, 2014). With more concerns due to recent droughts, the use of this source of water for a useful purpose, such as agricultural and other plant production, is sensible, since most of them contain organic matter, as well as $\mathrm{N}, \mathrm{P}$ and $\mathrm{K}$ compounds, nutrients that need to be added as fertilizers to achieve adequate yields providing these ingredients (Muyen et al., 2011). Farmers, particularly those in the continental regions, are interested in the use of wastewater in the measure where it has to pass a good treatment (Meneses et al., 2010). According to FAO (2010), treated wastewater is spread in over 20 million hectares of land worldwide. At the same time, in line with wastewater utilization practices, several advanced technology treatments have been built for agricultural and landscape irrigation, particularly in arid and semi-arid regions (Sato et al., 2013).

The recovery of treated wastewater (TWW) is considered as an essential component in the integrated water resources management policy (Larsen et al., 2016). In fact, the richness of treated wastewater with nutrients will contribute to the recycling of these elements and the reduction of the excessive use of fertilizers (Mouhani et al., 2012). Currently, Algeria has 134 treatment stations, WWTP (waste water treatment plants) and lagoons, in operation with an installed capacity estimated at 12 million EQH (equivalent population) or $800 \mathrm{hm}^{3} /$ year. In Algeria, wastewater will represent a very significant volume of almost two billion $\mathrm{m}^{3}$, if the demand for water is completely satisfied at this time. With this volume, once purified, for ecological considerations or protection of water resources, will be highly appreciated as to its use by agriculture or industry (De Fraiture and Wichelns, 2010). The reuse of treated wastewater, especially for agricultural purposes, has become one of the main focuses of the strategy of the water resources sector in Algeria (Kellis et al., 2013).

Many research studies and projects have been accomplished on the practice and effects of wastewater as irrigation source on different crops (Pedrero et al., 2010; Malchi et al., 2014), by increasing the amount of minerals in the foliage of the plants (Bedbabis et al., 2010; Carbonell et al., 2011; Bañón et al., 2011).

The reuse of wastewater requires close coordination between the different structures involved in reuse operations at all levels. Tomato is included in the category of industrial crops allowed for this irrigation practice (Gatta et al., 2015). Here, we present the results of a diagnostic greenhouse study in which we investigated the effects of treated wastewater application on the 


\section{EFFECT OF TREATED WASTEWATER IRRIGATION ON TOMATO GROWTH}

germination and growth of three tomato (Lycorpersicon esculentum) varieties, commonly grown crops in Algeria.

The main aim of the study was to develop a rapid assessment methodology for evaluating treated wastewater effect, by investigating the toxicity of the wastewater to both seed germination and vegetative plant growth.

\section{MATERIAL AND METHODS}

\section{Plant material, growth condition and treatment}

Experiments were conducted in greenhouse of the Regional Enterprise of Rural Engineering (RERE Aures, Batna, Algeria) (Lat: $35^{\circ} 33^{\prime} 45.40 " \mathrm{~N}$; Long: $\left.6^{\circ} 10^{\prime} 38.07 " \mathrm{E}\right)$. Treated wastewater (TWW) of the National Sanitation Office Maintenance Management Directorate Batna Unit WWTP-Timgad (Algeria) (Lat: $35^{\circ} 29^{\prime} 58.99^{\prime \prime N}$; 62ㅇ'20.19"E) was used in 2018 as irrigation water. Water quality parameters are provided in Table 1.

According to this table, the determination of nutrients shows relatively low concentrations of nitrates, nitrites and orthophosphate (the maxima in mg. $\mathrm{L}^{-1}$ are, respectively, $3.4,0.1$ and 4.84 ), whereas the ammonium level was $2.75 \mathrm{mg} \cdot \mathrm{L}^{-1}$.

The TWW pollutants has demonstrated that oxygen demands (COD and $\mathrm{BOD})$ reach low values $(\mathrm{COD}=$ $\left.51 \mathrm{mg} \mathrm{O} \cdot \mathrm{L}^{-1}, \mathrm{BOD}=3.25 \mathrm{mg} \cdot \mathrm{L}^{-1}\right)$. It is also the case for temperature, electrical conductivity (EC), salinity and $\mathrm{pH}$. Heavy metal concentrations are under the detection limit.

Effluent waters were stored in 20-liter tanks. The TWW was used undiluted
$(100 \% \mathrm{TWW})$, and at concentrations of $50 \%$ TWW and $0 \%$ TWW (control: groundwater).

Dilutions were performed using groundwater. Irrigations have been performed in frequent intervals to create water stress on plants. Excess water was drained from the pot under free drainage conditions. The seeds of three tomato (Lycopersicon esculentum L.) varieties (viz. Toufan, Heinz and Bouzina) have been used and compared. The 1000-seed weight was between 25 and $28 \mathrm{~g}$.

Table 1 - Wastewater Treatment Annual Report for 2018 (Wastewater treatment plants WWTP-Timgad, Batna)

\begin{tabular}{|c|c|}
\hline Parameters & Values \\
\hline SM $\left(m g \cdot L^{-1}\right)$ & $1.65 \pm 0.94$ \\
\hline BOD5 (mg. $\left.\mathrm{L}^{-1}\right)$ & $3.25 \pm 0.54$ \\
\hline $\operatorname{COD}\left(\mathrm{O}_{2} \cdot \mathrm{L}^{-1}\right)$ & $51.0 \pm 18.34$ \\
\hline $\mathrm{N}-\mathrm{NH}_{4}\left(\mathrm{mg}^{-\mathrm{L}^{-1}}\right)$ & $2.75 \pm 2.33$ \\
\hline $\mathrm{N}-\mathrm{NO}_{2}\left(\mathrm{mg} \cdot \mathrm{L}^{-1}\right)$ & $0.10 \pm 0.05$ \\
\hline $\mathrm{N}-\mathrm{NO}_{3}\left(\mathrm{mg} \cdot \mathrm{L}^{-1}\right)$ & $3.40 \pm 2.52$ \\
\hline $\mathrm{PO}_{4}^{3^{-3}}\left(\mathrm{mg} \cdot \mathrm{L}^{-1}\right)$ & $4.84 \pm 3.30$ \\
\hline Dissolved $\mathrm{O}_{2}$ & $4.83 \pm 1.10$ \\
\hline Salinity $\left(\mu \mathrm{S} . \mathrm{cm}^{-1}\right)$ & $0.43 \pm 0.04$ \\
\hline Conductivity $\left(\mu \mathrm{S} . \mathrm{cm}^{-1}\right)$ & $1133.5 \pm 72.1$ \\
\hline Temperature $\left({ }^{\circ} \mathrm{C}\right)$ & $15.7 \pm 4.23$ \\
\hline pH & $7.56 \pm 0.16$ \\
\hline
\end{tabular}

Suspended matter (MES), Biological oxygen demand (BOD5), Chemical oxygen demand (COD), Ammonium $\left(\mathrm{NH}_{4}{ }^{+}\right)$, Nitrite $\left(\mathrm{NO}_{2}{ }^{-}\right)$, Nitrate $\left(\mathrm{NO}_{3}{ }^{-}\right)$, Orthophosphates $\left(\mathrm{PO}_{4}{ }^{3-}\right)$.

\section{Seed germination parameter}

The experiment was conducted at the Laboratory of Ecology and Environment Department, University of Batna 2, Algeria (Lat: $35^{\circ} 38^{\prime} 10.32^{\prime \prime} \mathrm{N}$; Long: $6^{\circ} 16^{\prime} 31.52 \mathrm{E}$ ). The sowing (four replicates of 25 seeds $\times$ three treatments $\times$ three varieties) was realized in Petri dishes of $10 \mathrm{~cm}$ diameter, papered with two layers of Whatman filter paper and 


\section{ZOUAGRI, F. BEKHOUCHE, A. KHELOUFI, L. NOURI}

soaked with $20 \mathrm{ml}$ with the appropriate solution $(50 \%$ and $100 \%$ of TWW) or groundwater for the control $(0 \%$ TWW $)$. Seeds were incubated under continuous dark at the laboratory temperature $25^{\circ} \mathrm{C}$ $\left( \pm 2{ }^{\circ} \mathrm{C}\right)$.

The papers were changed with the same treatment each three days to prevent waste accumulation. The seeds were moistened with the appropriate solutions of TWW and kept wet throughout the 15 days of the experiment. The germination criterion was taken into account when radicle had pierced the tegument with $2 \mathrm{~mm}$ in length (Egley and Chandler, 1978).

The Petri dishes were arranged every two days, according to a randomized design to eliminate any effect of the position in the seed culture room.

Only the final germination percentage (FGP) for each tomato varieties and irrigation-treatment were calculated using the following formula:

$$
F G P(\%)=\frac{\Sigma n i}{N} \times 100
$$

where, $F G P$ is final germination percentage, $\mathrm{ni}$ is the number of germinated seeds at final day of test, and $N$ is the total number of incubated seeds per test (Côme, 1970).

\section{Morpho-physiological parameters}

Seeds were germinated in plastic pot (Top diameter: $28 \mathrm{~cm}$; Bottom diameter: $20 \mathrm{~cm}$; Height: $24 \mathrm{~cm}$ ) containing $4.5 \mathrm{~kg}$ of mixed substrate (two volumes of sand mixed with one volume of compost) $\left(\mathrm{EC}=1200 \mathrm{Ohm} \cdot \mathrm{cm}^{-1} ; \mathrm{pH}=5.0-6.5\right.$; $\mathrm{NPK}=1.2 \mathrm{~kg} \cdot \mathrm{m}^{-3} ; \mathrm{N}=30 \mathrm{~g} \cdot \mathrm{m}^{-3} ; \mathrm{P}_{2} \mathrm{O}_{5}=$
25 g.m $\mathrm{m}^{-3} ; \mathrm{K}_{2} \mathrm{O}=50$ g.m $\mathrm{m}^{-3}$ ) and arranged according to the method of complete randomized blocks with (four replicates $\times$ three treatments $\times$ three varieties) under greenhouse conditions. Sand was sieved at $2 \mathrm{~mm}$ to eliminate wastes and coarser material.

After 120 days of treatment, leaf, stem, and root samples were harvested from control and TWW-treated plants for estimation of various parameters.

Stem length (SL), root length (RL) and leaves number per plant (LNP) of four plants $(n=4)$ from each treatment were recorded after 120 days of treatment. For measurement of dry weights, leaves, stems and roots were excised from control and wastewater-treated plants and the fresh weight was noted immediately. Later, they were wrapped in pre-weighed aluminium foils and kept in an incubator at $80^{\circ} \mathrm{C}$ for $48 \mathrm{~h}$ before the dry weight was recorded.

Leaf fresh weight (LFW) was immediately noted after sampling and subsequently immersed into distilled water for $8 \mathrm{~h}$ at room temperature.

Leaves were then blotted dry and leaf turgid weight (LTW) was taken prior to incubating at $80^{\circ} \mathrm{C}$ for $48 \mathrm{~h}$. After incubation period, leaf dry weight (LDW) was also noted.

The leaf relative water content (RWC) was calculated using following formula (Barrs and Weatherley, 1962):

$$
R W C(\%)=\frac{L F W-L D W}{L T W-L D W} \times 100
$$

The rate water loss (RWL) was calculated using (Clarke et al., 1989) formula:

$$
R W L(m g / c m 2 . \min )=\frac{(F W-F W 2 h) / D W}{L A \times 120}
$$




\section{EFFECT OF TREATED WASTEWATER IRRIGATION ON TOMATO GROWTH}

where, $F W=$ leaf fresh weight determined immediately after leaf harvesting; $F W 2 h=$ leaf fresh weight measured after $120 \mathrm{~min}$., under laboratory conditions; $D W=$ leaves dry weight measured after drying in an oven at $50^{\circ} \mathrm{C}$, for $2 \mathrm{~h}$; LA = leaf area $\left(\mathrm{cm}^{2}\right)$, estimated by the method of Paul et al. (1979).

\section{Statistical analysis}

All the experiments were conducted with four replicates $(n=4)$ and the results were expressed as mean \pm standard deviation (SD). All the data were subjected to one-way (treatment) and twoway (treatment, varieties) analysis of variance (ANOVA) and Duncan's multiple-range test $(p<0.05)$ using SAS Version 9.0 (Statistical Analysis System) (2002) software.

\section{RESULTS AND DISCUSSION}

\section{Seed germination}

Fig. 1 showed the variation in seed germination rate of three tomato varieties (Heinz, Toufan and Bouzina) subjected to different treatments (three types of treated wastewater irrigation at different concentrations: $0 \%, 50 \%$ and $100 \%$ ). This figure showed that the FGP was not negatively affected by TWW concentration. Indeed, the increase in TWW concentration improved the FGP of the variety Heinz, decreased slightly the FGP of Toufan at $50 \%$ TWW and had no effect on Bouzina seeds. We clearly observed the positive effect of irrigation with treated wastewater, compared to groundwater. The delay in germination differed between species and is likely due to variation in seed size, seed coat permeability, differential uptake of nutrients and toxins and metabolism.

The maximum germination rate was recorded at the $50 \%$ treatment level for both Toufan and Bouzina varieties, registering respective values of $97 \%$ and $95 \%$. On the other hand, for the Heinz variety, the highest germination rate was recorded under $100 \%$ TWW irrigation with a value of $75 \%$ (Fig. 1). The analysis of twofactor variance (Table 2) showed a significant difference between the three treatments, for the germination rate parameter in both Heinz and Toufan varieties. However, Bouzina variety showed a similar way in the three treatments, justifying the nonsignificance of the result by recording germination rates fairly close.

The wastewater individually increased the biomass and NPK resulting in taller and leafier plants as compared to tap water (Farooq et al., 2010). The plants survival in a given environment depends in part on their reaction at the germinal stage (Mansouri and Kheloufi, 2017) and becomes the most important factor for the continuity of the life cycle of the plant (Bewley et al., 2012). Bedouh and Bekhouche (2014) reported that TWW treatment has a positive effect on onion (Allium cepa) seedlings emergence. These results indicated a tolerance of these seeds to the unfavorable conditions of the medium. According to Sharma (2012), the mechanisms of high catalase and peroxidase capacities in cotyledons contribute to the detoxification and restoration of 
thermodynamic equilibrium with the medium.

The results of Marzougui et al. (2018) showed that treated urban wastewater had a better contribution to the germination rate of hina (Lawsonia inermis). The causes of the variability of the germinative properties are numerous and depend mainly on the genetic heritage. Environmental factors may alter the expression of these genetic properties (Côme, 1970).

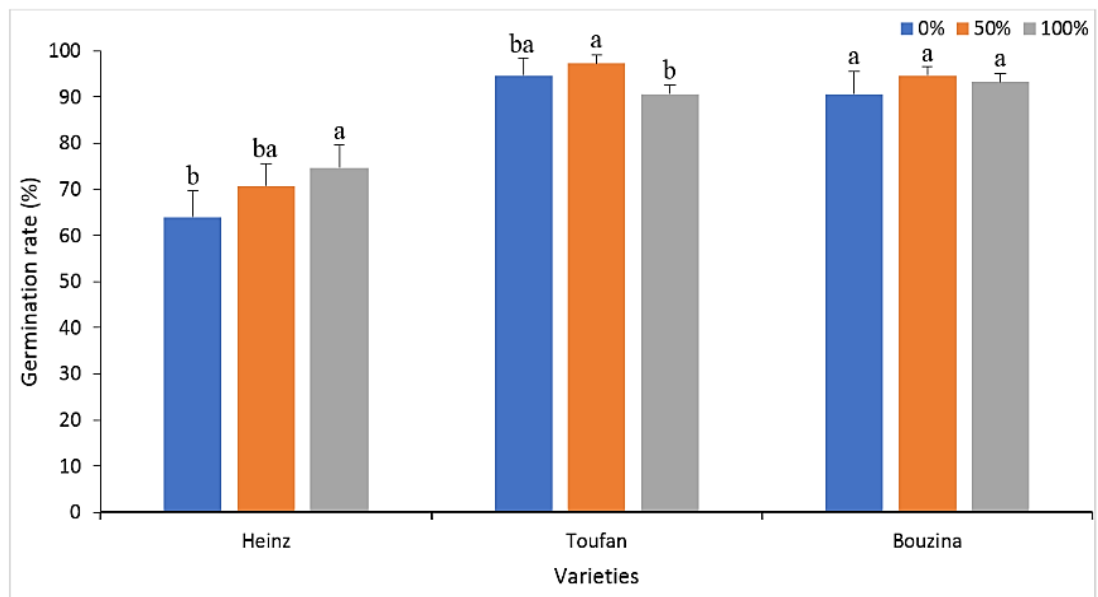

Figure 1 - Effect of treated wastewater irrigation on final germination rate of three tomato varieties after 15 days of various levels of treatments. Means, in each box, with similar letters are not significantly different at the $5 \%$ probability level using Duncan's test.

\section{Morphological traits}

According to Fig. 2, the leaves number and the root length for the three tomato varieties was not statistically influenced by the irrigation level. Indeed, the values are fairly close together where the lowest number of leaves was recorded in the Bouzina variety.

The SL was influenced by the type of treatment in the three varieties of tomato, where the most remarkable effect was noted in Bouzina and Heinz varieties (Fig. 2). However, the change in stem length in Toufan variety was not influenced by the level of irrigation by recording fairly close average values (Fig. 2).

Overall, the number of leaves, stem length and root length are higher in the $50 \%$ and $100 \%$ TWW-irrigated Toufan variety (Table 2, Fig. 2). The first plant part interacts with soil and irrigation solution is the roots and it is almost inevitable that the crops are affected by salt or other mineral concentration (Kheloufi et al., 2016; Kheloufi et al., 2018). The reason that the root and shoot length are affected negatively by TWW is due to the inhibition of cytokinesis and cell expansion (Han et al., 2011). The increase in osmotic pressure around the roots because of rhizosphere 


\section{EFFECT OF TREATED WASTEWATER IRRIGATION ON TOMATO GROWTH}

environment can also prevent water uptake by root and results with short root (Özkara et al., 2011).

\section{Plant dry biomass}

According to Fig. 3, no significant effect was observed on the dry biomass of the leaves, stems and roots of Toufan variety plants at the three treatment levels. In addition, this variety showed the highest values for dry biomass for the three organs studied.

Table 2 - Mean comparison and analysis of variance effects of treated wastewater irrigation on FGP (final germination percentage), LN (leaves number), LDW (leaves dry weight), SL (stem length), SDW (stem dry weight), RL (root length), RDW (root dry weight), RWC (relative water content) and RWL (rate water loss)

\begin{tabular}{|c|c|c|c|c|c|}
\hline Parameters & $\begin{array}{l}\text { Sources of } \\
\text { variation }\end{array}$ & Df & $\mathbf{F}$ & $p$ & $\begin{array}{c}\text { Duncan's multirange } \\
\text { test }\end{array}$ \\
\hline \multirow{3}{*}{ FGP } & TRT & 2 & 4.16 & 0.0267 & \multirow{3}{*}{$\begin{array}{c}\text { Heinz }^{\mathrm{B}} \\
\text { Toufan }^{\mathrm{A}} \\
\text { Bouzina }^{\mathrm{A}}\end{array}$} \\
\hline & VAR & 2 & 151.00 & $<0.0001$ & \\
\hline & TRT $\times$ VAR & 4 & 3.84 & 0.0135 & \\
\hline \multirow{3}{*}{ LN } & TRT & 2 & 5.30 & 0.0115 & \multirow{3}{*}{$\begin{array}{c}\text { Heinz }^{\mathrm{A}} \\
\text { Toufan }^{\mathrm{A}} \\
\text { Bouzina }^{\mathrm{A}}\end{array}$} \\
\hline & VAR & 2 & 1.46 & 0.2505 & \\
\hline & TRT $\times$ VAR & 4 & 1.45 & 0.2461 & \\
\hline \multirow{3}{*}{ LDW } & TRT & 2 & 1.84 & 0.1785 & \multirow{3}{*}{$\begin{array}{c}\text { Heinz }^{\mathrm{B}} \\
\text { Toufan }^{\mathrm{A}} \\
\text { Bouzina }^{\mathrm{B}}\end{array}$} \\
\hline & VAR & 2 & 5.02 & 0.0140 & \\
\hline & TRT $\times$ VAR & 4 & 2.61 & 0.0577 & \\
\hline \multirow{3}{*}{ SL } & TRT & 2 & 7.01 & 0.0035 & \multirow{3}{*}{$\begin{array}{c}\text { Heinz }^{\mathrm{B}} \\
\text { Toufan }^{\mathrm{A}} \\
\text { Bouzina }^{\mathrm{C}}\end{array}$} \\
\hline & VAR & 2 & 22.61 & $<0.0001$ & \\
\hline & TRT $\times$ VAR & 4 & 3.65 & 0.0167 & \\
\hline \multirow{3}{*}{ SDW } & TRT & 2 & 3.60 & 0.0412 & \multirow{3}{*}{$\begin{array}{c}\text { Heinz }^{\mathrm{B}} \\
\text { Toufan }^{\mathrm{A}} \\
\text { Bouzina }^{\mathrm{B}}\end{array}$} \\
\hline & VAR & 2 & 10.21 & 0.0005 & \\
\hline & TRT $\times$ VAR & 4 & 3.85 & 0.0133 & \\
\hline \multirow{3}{*}{$\mathbf{R L}$} & TRT & 2 & 4.00 & 0.0301 & \multirow{3}{*}{$\begin{array}{c}\operatorname{Heinz}^{\mathrm{A}} \\
\operatorname{Toufan}^{\mathrm{A}} \\
\text { Bouzina }^{\mathrm{A}}\end{array}$} \\
\hline & VAR & 2 & 0.53 & 0.5929 & \\
\hline & TRT $\times$ VAR & 4 & 2.67 & 0.0534 & \\
\hline \multirow{3}{*}{ RDW } & TRT & 2 & 2.62 & 0.0913 & \multirow{3}{*}{$\begin{array}{c}\text { Heinz }^{\mathrm{A}} \\
\operatorname{Toufan}^{\mathrm{A}} \\
\text { Bouzina }^{\mathrm{A}}\end{array}$} \\
\hline & VAR & 2 & 0.81 & 0.4566 & \\
\hline & TRT $\times$ VAR & 4 & 1.44 & 0.2490 & \\
\hline \multirow{3}{*}{ RWC } & TRT & 2 & 1.01 & 0.3779 & \multirow{3}{*}{$\begin{array}{c}\text { Heinz }^{\mathrm{B}} \\
\text { Toufan }^{\mathrm{A}} \\
\text { Bouzina }^{\mathrm{B}}\end{array}$} \\
\hline & VAR & 2 & 21.80 & $<0.0001$ & \\
\hline & TRT $\times$ VAR & 4 & 3.69 & 0.0161 & \\
\hline \multirow{3}{*}{ RWL } & TRT & 2 & 0.30 & 0.7456 & \multirow{3}{*}{$\begin{array}{c}\text { Heinz }^{\mathrm{A}} \\
\text { Toufan }^{\mathrm{A}} \\
\text { Bouzina }^{\mathrm{A}}\end{array}$} \\
\hline & VAR & 2 & 1.47 & 0.2480 & \\
\hline & TRT $\times$ VAR & 4 & 1.02 & 0.4128 & \\
\hline
\end{tabular}




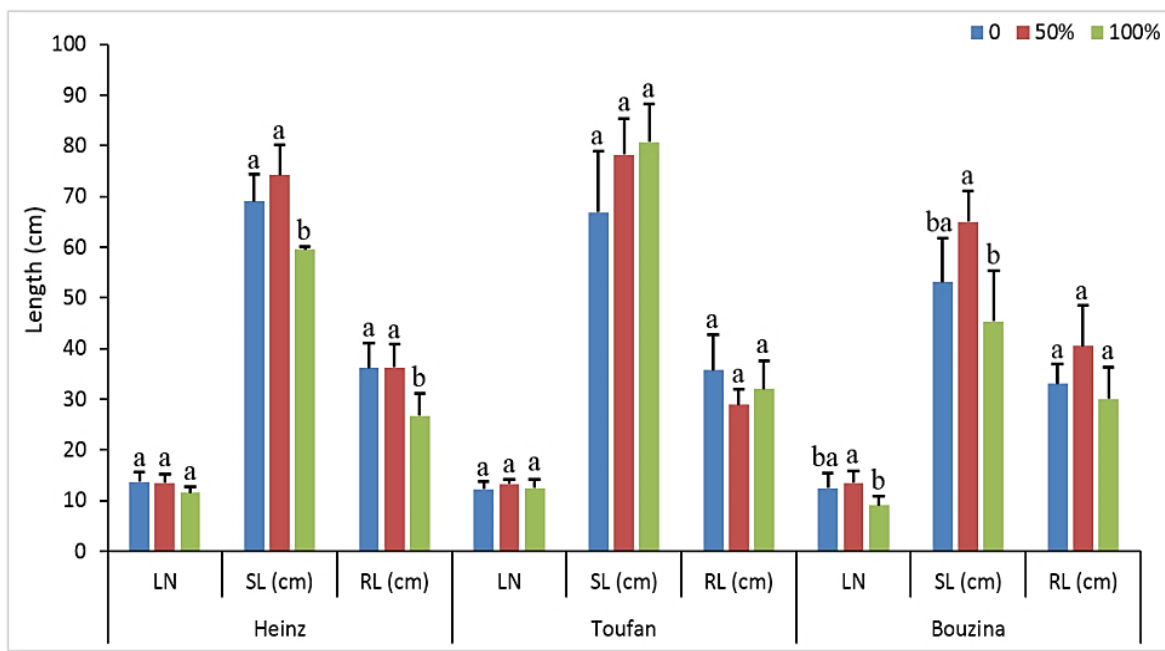

Figure 2 - Effect of treated wastewater irrigation on leaves number (LN), stem length $(\mathrm{SL})$ and root length (RL) of three tomato varieties after 120 days of various levels of treatments. Means, in each box, with similar letters are not significantly different at the $5 \%$ probability level using Duncan's test.

According to Bedouh (2012), the production of biomass is greater in plants watered by TWW than those of the controls. According to Fig. 3, TWW irrigation seems to significantly affect the dry biomass of Bouzina variety plants. In fact, $100 \%$ TWW irrigation reduced this biomass by $80 \%$ in the leaves, $72 \%$ in the stems and $72 \%$ in the roots, compared to control. However, no effect was observed by $50 \%$ TWW irrigation. For Heinz variety, the only effect of TWW irrigation was observed on SDW (Fig. 3). The increase in TWW concentration decreased the dry biomass by $65 \%$ at $100 \%$ TWW.

It is not yet known which components of the wastewater are likely to be responsible for the chronic phytotoxicity observed (MichaelKordatou et al., 2015). However, there is some evidence suggesting that sodium (Netzer et al., 2014), ethanol (Ge et al., 2012) and polyphenols (Barbera et al., 2013) are all potentially phytotoxic constituents. The detailed analysis of inorganic components in the root and shoot tissue provided some insights (Tangahu et al., 2013). Research further revealed that salinity plays an important role in the quality of wastewater. Indeed, salinity not only affects seed germination (Mansouri and Kheloufi, 2017), but also significantly reduced the subsequent growth of seedlings (Shelef et al., 2013). This reduction in seedling growth is either due to accumulation of mineral ions in their cell sap or because of the failure of sub-cellular organelles to adjust high osmotic potential of cell sap (Lisar et al., 2012). 


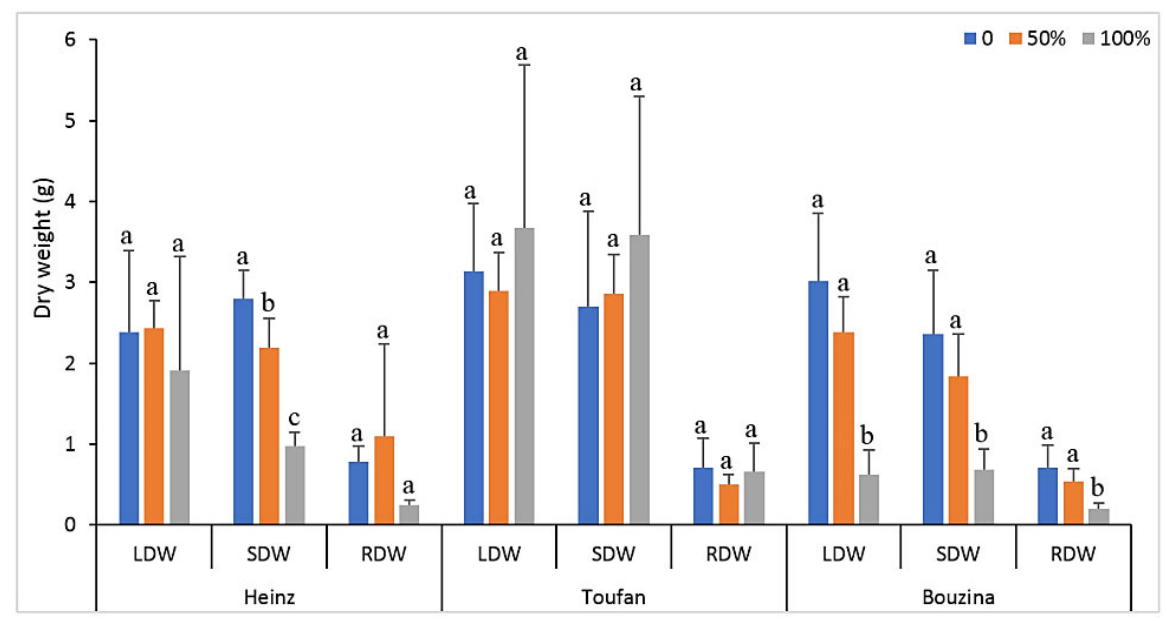

Figure 3 - Effect of wastewater irrigation on leaves dry weight (LDW), stem dry weight (SDW) and root dry weight (RDW) of three tomato varieties after 120 days of various levels of treatments. Means, in each box, with similar letters are not significantly different at the $5 \%$ probability level using Duncan's test.

\section{Physiological traits}

According to Fig. 4, no significant effect was observed on the RWC of the leaves of Toufan variety plants at the three treatment levels. In addition, this variety showed the highest values of RWC, compared to Heinz and Bouzina varieties. Indeed, TWW irrigation did not produce a notable change in the water content of the plants leaves, indicating a relatively high resistance as well to dehydration, which will certainly contribute to some degree of TWW tolerance.

For Bouzina variety, the RWC decreased slightly with increase in TWW at $50 \%$ (Fig. 4). However, the RWC increases under $100 \%$ TWW with a mean value similar to the control. The opposite phenomenon was observed in the Heinz variety where RWC decreases only under $100 \%$ TWW recording a loss of $11 \%$, compared to control (Fig. 4).

According to Fig. 5, no significant effect was observed on the RWL of the leaves of both Heinz and Toufan varieties at the three treatment levels. Indeed, TWW irrigation did not produce a notable change in the water loss of the plants leaves, which will certainly contribute to some degree of TWW tolerance.

This improvement could be due to stomatal closure, it will typically induce the limitation of gas exchange and alter the rate of photosynthesis and metabolism (Wang and Nii, 2000). 


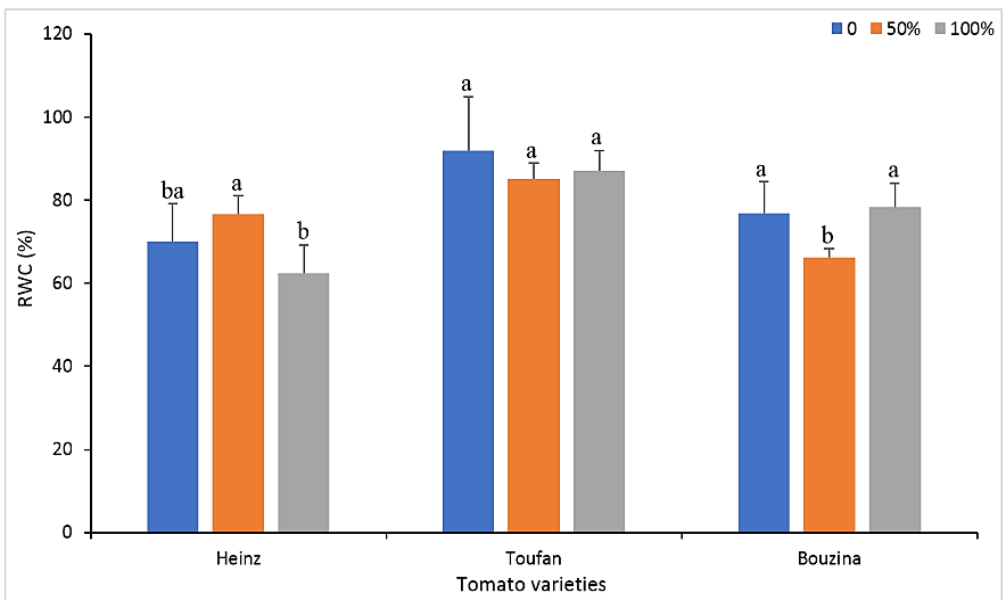

Figure 4 - Effect of treated wastewater irrigation on relative water content (RWC)

from the leaves of three tomato varieties after 120 days of various levels of treatments. Means, in each box, with similar letters are not significantly different at the $5 \%$ probability level using Duncan's test.

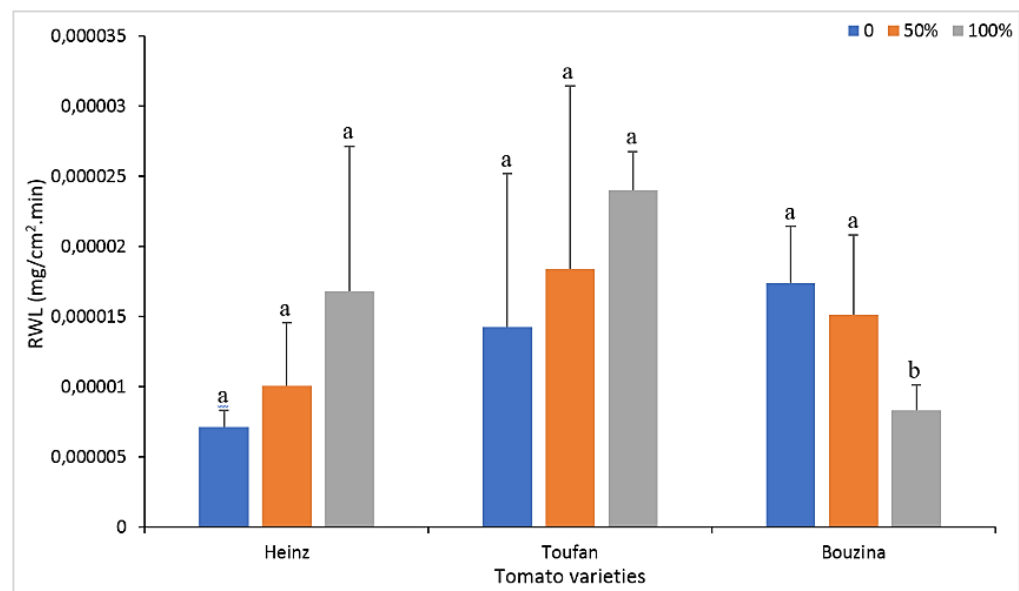

Figure 5 - Effect of treated wastewater irrigation on the rate water loss (RWL) from the leaves of three tomato varieties after 120 days of various levels of treatments.

Means, in each box, with similar letters are not significantly different at the $5 \%$ probability level using Duncan's test.

RWL and RWC have been suggested as screening techniques to identify genotypes under drought stress (Gunes et al., 2008). Indeed, these traits are direct measurements of plant water deficit and good criterions for the selection of drought tolerant plants (Farshadfar et al., 2001). This tolerance is also depending on the plant capacity to accumulate many minerals $(\mathrm{NaCl}$ or heavy metals) in the vacuole, to avoid reaching toxic 


\section{EFFECT OF TREATED WASTEWATER IRRIGATION ON TOMATO GROWTH}

concentrations in the cytoplasm, a mechanism that is especially efficient in some succulent, highly tolerant dicotyledonous halophytes (Ruiz and Blumwald, 2002). On the other hand, the only tomato variety affected by TWW irrigation was Bouzina variety whose leaves recorded a reduced RWL to $53 \%$, compared to the control (Fig. 5).

\section{CONCLUSIONS}

This study has demonstrated that treated wastewater improves the germination in Heinz variety and had no effect on both Toufan and Bouzina varieties whether it is pure or diluted by half. The statistical analysis showed that the Toufan variety has tolerated successfully the TWW irrigation with its high and moderate concentrations, and this by analysing all the morpho-physiological parameters studied in this work. The use of TWW with dilution is therefore practically limited based on freshwater availability and cost, in conjunction with overall volumes of treated wastewater production. Using the TWW as irrigation water would be a great help and we will economize groundwater even if we have to use a diluted TWW at a low concentration.

\section{REFERENCES}

Bañón, S., Miralles J., Ochoa J., Franco J.A. \& Sánchez-Blanco, M.J. (2011). Effects of diluted and undiluted treated wastewater on the growth, physiological aspects and visual quality of potted lantana and polygala plants. Sci.Hortic., 129(4): 869-876, DOI: 10.1016/j.scienta.201 1.05.027

Barbera, A.C., Maucieri, C., Cavallaro, V., loppolo, A. \& Spagna, G. (2013). Effects of spreading olive mill wastewater on soil properties and crops. Agric. Water Manag., 119: 43-53, DOI: 10.1016/j.agwat. 2012.12.009

Barrs, H.D. \& Weatherley, P.E. (1962). A re-examination of the relative turgidity technique for estimating water deficits in leaves. Aust.J. Biol.Sci., 15(3): 413-428, DOI: 10.1071/BI9620413

Bedbabis, S., Ferrara, G., Rouina, B.B. \& Boukhris, M. (2010). Effects of irrigation with treated wastewater on olive tree growth, yield and leaf mineral elements at short term. Sci.Hortic., 126(3): 345-350, DOI: 10.1016/j.scienta.2010.07.020

Bedouh, Y. \& Bekhouche, F. (2012). Influence of treated wastewater irrigation on some biochemical parameters of onion (Allium cepa). Ann.Biol.Res., 3(10): 4820-4827.

Bewley, J.D., Bradford, K., Hilhorst, H. \& H. Nonogaki (2012). Seeds: physiology of development, germination and dormancy. Science and Business Media, $392 \mathrm{p}$.

Carbonell, G., de Imperial, R.M., Torrijos, M., Delgado, M. \& Rodriguez, J.A. (2011). Effects of municipal solid waste compost and mineral fertilizer amendments on soil properties and heavy metals distribution in maize plants (Zea mays L.). Chemosphere, 85(10): 1614-1623, DOI: 10.1016/j. chemo sphere.2011.08.025

Clarke, J.M., Romagosa, I., Jana, S., Srivastava J.P. \& McCaig T.N. (1989). Relationship of excised-leaf water loss rate and yield of durum wheat in diverse environments. Can.J.Plant Sci., 69: 1075-1081, DOI: $10.4141 /$ cjps89-130 
Côme, D. (1970). Obstacles to germination. Ed. Masson, Paris, $162 \mathrm{p}$.

De Fraiture, C. \& Wichelns, D. (2010). Satisfying future water demands for agriculture. Agric. Water Manag., 97(4): 502-511, DOI: 10.1016/j.agw at.2009.08.008

Egley, G.H. \& Chandler, J.M. (1978). Germination and viability of weed seeds after 2.5 years in a 50 -Year buried seed Study. Weed Sci., 26(3): 230-239, DOI: $10.1017 /$ S004317450 004978X

FAO (2010). FAOSTAT: Live animals. Available at: http://faostat.fao.org/ site/573/defaulf.aspx\#ancor

Farshadfar, E., Farshadfar, M. \& Sutka, J. (2001). Combining ability analysis of drought tolerance in wheat over different water regimes. Acta Agronomica Hung., 48(4): 353-361, DOI: $10.1556 / A A g r .48 .2000 .4 .5$

Farooq, H., Batool, N., Iqbal, J. \& Nouman, W. (2010). Effect of salinity and municipal wastewater on growth performance and nutrient composition of Acacia nilotica $\mathrm{L}$. Int.J.Agric.Biol., 12(4): 591-596.

Gatta, G., Libutti, A., Gagliardi, A., Beneduce, L., Brusetti, L., Borruso, L., Disciglio, G. \& Tarantino, E. (2015). Treated agroindustrial wastewater irrigation of tomato crop: effects on qualitative/ quantitative characteristics of production and microbiological properties of the soil. Agric. Water Manag., 149: 33-43, DOI: 10.1016/j. agwat.2014.10.016

Ge, X., Zhang, N., Phillips, G.C. \& Xu, J. (2012). Growing Lemna minor in agricultural wastewater and converting the duckweed biomass to ethanol. Bioresour.Technol., 124: 485-488, DOI: 10.1016/j.biortech. 2012.08.050

Gunes, A., Inal, A., Adak, M.S., Bagci, E.G., Cicek, N. \& Eraslan, F. (2008). Effect of drought stress implemented at pre-or post-anthesis stage on some physiological parameters as screening criteria in chickpea cultivars. Russ.J.Plant Physiol., 55(1): 59-67, DOI: 10.1134 /S102144370801007X

Han, M., Li, G., Sang, N. \& Dong, Y. (2011). Investigating the bio-toxicity of coking wastewater using Zea mays L. Ecotox.Environ.Safe., 74(4): 1050-1056, DOI: 10.1016/j.ecoenv. 2011.01.023

Jones, J.A.A. (2014). Global hydrology: processes, resources and environmental management. $1^{\text {st }}$ Edition, London, Routledge, 414 p.

Kellis, M., Kalavrouziotis, I.K. \& Gikas, P. (2013). Review of wastewater reuse in the Mediterranean countries, focusing on regulations and policies for municipal and industrial applications. Global NEST J., 15(3): 333-350.

Kheloufi, A., Chorfi, A. \& Mansouri, L.M. (2016). The Mediterranean seawater: the impact on the germination and the seedlings emergence in three Acacia species. JBES, 8(6):238-249.

Kheloufi, A., Chorfi, A., Mansouri, L.M. \& Benyamina H. (2018). Morphophysiological characterization and photosynthetic pigment contents of Acacia karroo Hayne seedlings under saline conditions. Poljoprivreda $i$ Sumarstvo, 64(2): 87-99, DOI: 10.17707/AgricultForest. 64.2.06

Larsen, T.A., Hoffmann, S., Lüthi, C., Truffer, B. \& Maurer, M. (2016). Emerging solutions to the water challenges of an urbanizing world. Science, 352(6288): 928-933, DOI: 10.1126/science.aad8641

Lisar, S.Y.S., Motafakkerazad, R., Hossain, M.M. \& Rahman, I.M.M. (2012). Water stress in plants: causes, effects and responses In: Rahman, IMM (Ed.). Water Stress, pp. 1-14.

Loucks, D.P. \& van Beek E. (2005). Water resource systems planning and management: an introduction to methods, models, and applications. Springer, $690 \mathrm{p}$. 


\section{EFFECT OF TREATED WASTEWATER IRRIGATION ON TOMATO GROWTH}

Malchi, T., Maor, Y., Tadmor, G., Shenker, M. \& Chefetz, B. (2014). Irrigation of root vegetables with treated wastewater: evaluating uptake of pharmaceuticals and the associated human health risks. Environ.Sci.Technol., 48(16): 93259333, DOI: 10.1021/es5017894

Mansouri, L.M. \& Kheloufi, A. (2017). Effect of diluted seawater on seed germination and seedling growth of three leguminous crops (pea, chickpea and common bean). Poljoprivreda i Sumarstvo, 63(2): 131-142, DOI: 10.17707/Agricult Forest.63.2.11

Marzougui, N., Sabbahi, S., Guasmi, F., Hammami, A., Haddad, M. \& Rejeb, S. (2018). Effects of wastewater quality on Henna (Lawsonia inermis L.) germination and seedling growth: a case study, Tunisia. IJEAB, 3(1): 147-157, DOI: 10.22161/ijeab/3.1.19

Meneses, M., Pasqualino, J.C. \& Castells, F. (2010). Environmental assessment of urban wastewater reuse: treatment alternatives and applications. Chemosphere, 81(2): 266-272, DOI: 10.1016/j.chemo sphere.2010.05.053

Michael-Kordatou, I., Michael, C., Duan, X., He, X., Dionysiou, D.D., Mills, M.A. \& Fatta-Kassinos, D. (2015). Dissolved effluent organic matter: characteristics and potential implications in wastewater treatment and reuse applications. Water Res., 77: 213-248, DOI: 10.1016/j.watres. 2015.03.011

Mouhani, H., Hamdi, H., Bendou, A., Benzine, L. \& Cavalli, E. (2012). Impact de la réutilisation des eaux usées épurées en irrigation : analyse ionique des lixiviats, Water Sci., 25(1): 69-73, DOI: 10.7202/100853 $6 a r$

Muyen, Z., Moore, G.A. \& Wrigley, R.J. (2011). Soil salinity and sodicity effects of wastewater irrigation in South East Australia. Agric. Water
Manag., 99(1): 33-41, DOI: 10.1016/ j.agwat.2011.07.021

Netzer, Y., Shenker, M. \& Schwartz, A. (2014). Effects of irrigation using treated wastewater on table grape vineyards: dynamics of sodium accumulation in soil and plant. Irrigation Sci., 32(4): 283-294, DOI: 10.1007/s00271-014-0430-8

Özkara, A., Akyıl, D., Erdoğmuş, S.F. \& Konuk, M. (2011). Evaluation of germination, root growth and cytological effects of wastewater of sugar factory (Afyonkarahisar) using Hordeum vulgare bioassays. Environ.Monit.Assess., $\quad$ 183(1-4): 517-524, DOI: 10.1007/s10661-0111936-7

Pedrero, F., Kalavrouziotis, I., Alarcón, J.J., Koukoulakis, P. \& Asano, T. (2010). Use of treated municipal wastewater in irrigated agriculture Review of some practices in Spain and Greece. Agric. Water Manag., 97(9): 1233-1241, DOI: 10.1016/ j.agwat.2010.03.003

Ruiz, J. \& Blumwald, E. (2002). Salinityinduced glutathione synthesis in Brassica napus. Planta, 214(6): 965969, DOI: 10.1007/s00425-002-07 48-y

Sato, T., Qadir, M., Yamamoto, S., Endo, T. \& Zahoor, A. (2013). Global, regional, and country level need for data on wastewater generation, treatment, and use. Agricu. Water Manag., 130: 1-13, DOI: 10.1016/j.agwat.2013.08.007

Sharma, P., Jha, A.B., Dubey, R.S. \& Pessarakli, M. (2012). Reactive oxygen species, oxidative damage, and antioxidative defense mechanism in plants under stressful conditions (Review Article). J. Bot., 26 p., DOI: 10.1155/2012/217037

Shelef, O., Gross, A. \& Rachmilevitch, S. (2013). Role of plants in a constructed wetland: current and new perspectives. Water, 5(2): 405419, DOI: 10.3390/w5020405 


\section{ZOUAGRI, F. BEKHOUCHE, A. KHELOUFI, L. NOURI}

Tangahu, B.V., Abdullah, S.R.S., Basri, H., Idris, M., Anuar, N. \& Mukhlisin, M. (2013). Phytotoxicity of wastewater containing lead $(\mathrm{Pb})$ effects Scirpus grossus. Int.J. Phytoremediat, 15(8): 814-826, DOI: 10.1080/15226514.2012.736437

Wang, Y. \& Nii, N. (2000). Changes in chlorophyll, ribulose bisphosphate carboxylase-oxygenase, glycine betaine content, photosynthesis and transpiration in Amaranthus tricolor leaves during salt stress. The J.Hortic.Sci.Biotechnol., 75(6): 623627, DOI: 10.1080/14620316.2000. 11511297. 